\title{
Carstairs Cumming Douglas, M.D., D.Sc.
}

THE sudden death on September 28, 1940, of Dr Carstairs Cumming Douglas must inevitably be felt as a withdrawal of weight from extramural teaching in Glasgow and as a loss to the medical profession. One of a West of Scotland family, he was born in Fife and educated at George Watson's College. His Alma Mater was the University of Edinburgh, where he was a distinguished student and won many scholarships and prizes. Graduating as Bachelor of Medicine and Master of Surgery, with First Class Honours, in 1890 , he became a Doctor of Medicine, with Honours, of that University six years later. In 1906 he added to his academic distinctions by graduating as a Doctor of Science, and in I90 I became a Fellow of the Royal Society of Edinburgh. Dr Carstairs Douglas also spent a period of study in Berlin. His long and valuable association with the Anderson College of Medicine in Glasgow commenced in 1899 , when he received the appointment of Professor of Medical Jurisprudence and Public Health, which office he held with distinction until his death. During the long period of forty years he held numerous additional appointments, including the Deanship of Anderson College, the Chairmanship of the Council of the Medical and Dental Defence Union of Scotland, the Principal Lecturership in Hygiene, Glasgow Provincial Committee for the Training of Teachers, and the Examinerships for the Diploma in Public Health of the three Royal Scottish Medical Corporations and in Medical Jurisprudence for the Scottish Conjoint Board. During his long period as a teacher he gave of his best to the instruction of many generations of students, making his teaching a joy and inspiration, and he won the respect and esteem of all sections of a wide community. He proved himself a valued colleague and his unfailing courtesy and fair-mindedness endeared him to all. As an author, he wrote Chemical and Microscopical Aids to Diagnosis, The Laws of Health, A Manual of School Hygiene, in addition to numerous scientific papers. He is survived by his wife, also a son and daughter.

J. G. 